\title{
The $\mathrm{BCl}-2 / \mathrm{xL}$ inhibitor ABT-263 increases the stability of Mcl-1 mRNA and protein in hepatocellular carcinoma cells
}

\author{
Bin Wang ${ }^{1 \dagger}$, Zhenhong $\mathrm{Ni}^{1 \dagger}$, Xufang Dai ${ }^{2}$, Liyan Qin ${ }^{1}$, Xinzhe $\mathrm{Li}^{1}$, Liang $\mathrm{Xu}^{3}$, Jiqin Lian ${ }^{1 *}$ and Fengtian $\mathrm{He}^{1^{*}}$
}

\begin{abstract}
Background: Hepatocellular carcinoma (HCC) is one of the major causes of mortality. ABT-263 is a newly synthesized, orally available $\mathrm{BCl}-2 / \mathrm{xL}$ inhibitor that shows promising efficacy in HCC therapy. ABT-263 inhibits the anti-apoptotic activity of BCl-2 and BCl-xL, but not Mcl-1. Previous reports have shown that ABT-263 upregulates Mcl-1 in various cancer cells, which contributes to ABT-263 resistance in cancer therapy. However, the associated mechanisms are not well known.
\end{abstract}

Methods: Western blot, RNAi and CCK-8 assays were used to investigate the relationship between Mcl-1 upregulation and ABT-263 sensitivity in HCC cells. Real-time PCR and Western blot were used to detect Mcl-1 mRNA and protein levels. Luciferase reporter assay and RNA synthesis inhibition assay were adopted to analyze the mechanism of Mcl-1 mRNA upregulation. Western blot and the inhibition assays for protein synthesis and proteasome were used to explore the mechanisms of ABT-263-enhanced Mcl-1 protein stability. Trypan blue exclusion assay and flow cytometry were used to examine cell death and apoptosis.

Results: ABT-263 upregulated Mcl-1 mRNA and protein levels in HCC cells, which contributes to ABT-263 resistance. ABT-263 increased the mRNA level of Mcl-1 in HCC cells by enhancing the mRNA stability without influencing its transcription. Furthermore, ABT-263 increased the protein stability of Mcl-1 through promoting ERK-and JNK-induced phosphorylation of $\mathrm{MCl}-1^{\text {Thr163 }}$ and increasing the Akt-mediated inactivation of GSK-3B. Additionally, the inhibitors of ERK, JNK or Akt sensitized ABT-263-induced apoptosis in HCC cells.

Conclusions: ABT-263 increases Mcl-1 stability at both mRNA and protein levels in HCC cells. Inhibition of ERK, JNK or Akt activity sensitizes ABT-263-induced apoptosis. This study may provide novel insights into the Bcl-2-targeted cancer therapeutics.

Keywords: ABT-263, Mcl-1, Stability, HCC

\section{Background}

Hepatocellular carcinoma (HCC) is one of the major causes of mortality in developing countries, such as in China, and its prevalence ranks the fifth of all tumors with rapid increasing morbidity [1]. Currently, the efficacy of traditional chemotherapy for HCC is often unsatisfied [2]. Therefore, it is of great priority to develop novel molecular targeted compounds. Recent studies

\footnotetext{
*Correspondence: lianjiqin@sina.com; hefengtian06@aliyun.com ${ }^{\dagger}$ Equal contributors

'Department of Biochemistry and Molecular Biology, College of Basic Medical Sciences, Third Military Medical University, 30 Gaotanyan, Chongqing 400038, China

Full list of author information is available at the end of the article
}

have shown that the inhibitors of Bcl-2 exhibit promising antitumor activity [3].

Bcl-2 family consists of three categories of proteins, namely anti-apoptotic members, apoptosis executors and pro-apoptotic BH3-only proteins. The balance of these proteins contributes to survival and homeostasis of both normal and tumor cells [4]. However, overexpression of anti-apoptotic members $\mathrm{Bcl}-2$ and $\mathrm{Bcl}-\mathrm{xL}$ always happens in tumors and indicates a poor prognosis [5-8]. Meanwhile, previous reports have also shown that the levels of $\mathrm{Bcl}-2 / \mathrm{xL}$ are closely related to the pathological grade and survival rate of HCC $[9,10]$. These studies imply that 
Bcl-2/xL may serve as potential therapeutic targets for HCC.

Some of the Bcl-2 inhibitors (that have been) developed are a group of natural or synthesized compounds that target anti-apoptotic $\mathrm{Bcl}-2$ family members especially $\mathrm{Bcl}-2$ and Bcl-xL. ABT-263, also known as Navitoclax, is an orally available analog of ABT-737, which can bind to Bcl-2 and Bcl-xL, but not Mcl-1 [4]. Several studies have shown that ABT-263 exerts optimistic anti-tumor effects, especially in haematological malignancies and non-small cell lung cancer [11]. Furthermore, ABT-263 is now in phaseII clinical trials for several types of tumor with initial results $[12,13]$. However, previous studies have shown that ABT263 upregulates Mcl-1 protein, which ultimately contributes to drug resistance $[14,15]$.

Mcl-1 is an important anti-apoptotic protein that mainly distributes in mitochondria and cytoplasm. Mcl1 exerts anti-apoptotic effects by interacting with proapoptotic proteins such as Bim, Noxa, Bak and Bax. Also, Mcl-1 may function by facilitating normal mitochondrial fusion, ATP production and respiration [16]. Therefore, Mcl-1 protein level is elaborately regulated in both normal and tumor cells [17], among which phosphorylation modification is a quite significant way. Others reporting results and our previous data have shown that ABT-263 upregulates Mcl-1 in HCC cells, which is the crucial reason for ABT-263 resistance in cancer therapy. However, the associated mechanisms are not well known $[14,18]$. In the present study, we for the first time demonstrated that ABT-263 upregulated Mcl-1 by enhancing the stability of both Mcl-1 mRNA and protein, which contributed to ABT-263 resistance in HCC cells. Moreover, inhibition of ERK, JNK or Akt activity sensitized ABT-263-induced apoptosis. This study may provide novel insights into the Bcl-2-targeted cancer therapeutics.

\section{Results}

Upregulation of Mcl-1 is correlated with ABT-263 resistance in HCC cells

Firstly, the expression levels of anti-apoptotic Bcl-2 family members $\mathrm{Bcl}-2, \mathrm{Bcl}-\mathrm{xL}$ and $\mathrm{Mcl}-1$ were analyzed with Western blot in HCC cell lines PLC/PRF/5, Hep3B, HepG2 and Huh7. As shown in Figure 1A, Mcl-1 was highly expressed in all four HCC cell lines, but the levels
A

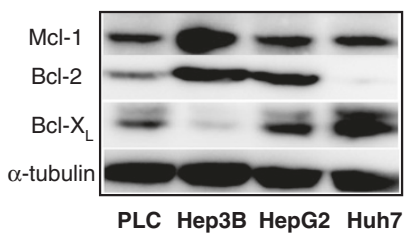

C

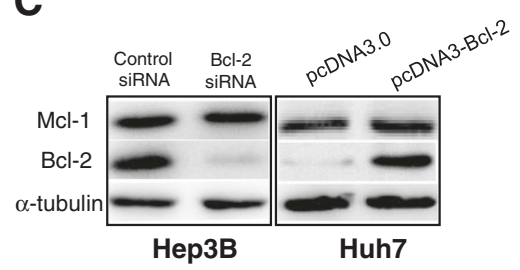

D

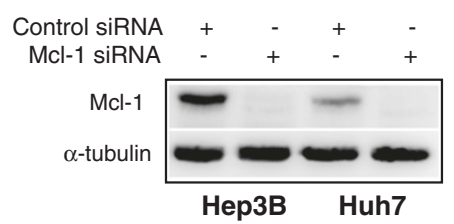

B

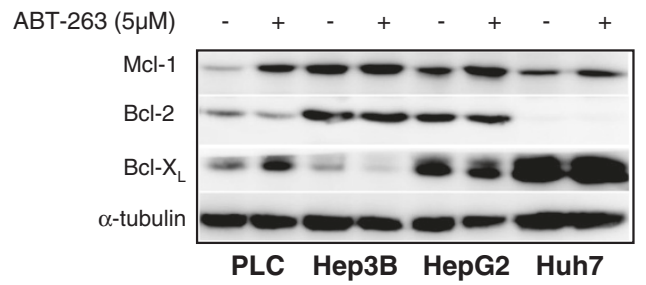

E

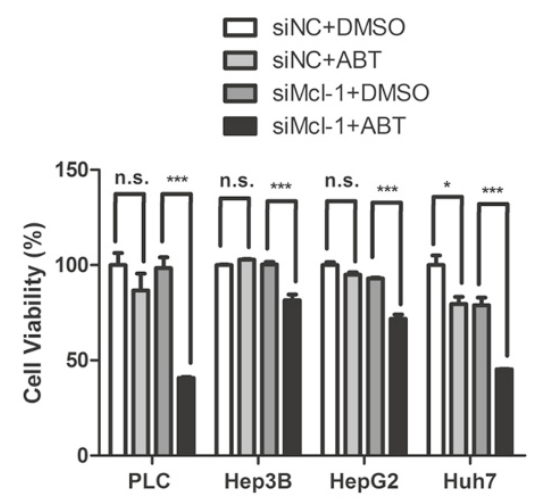

Figure 1 Upregulation of $\mathbf{M C l}-1$ is correlated with $\mathrm{ABT}-263$ resistance in $\mathrm{HCC}$ cells. (A) The expression profiles of $\mathrm{BCl}-2, \mathrm{BCl}-\mathrm{xL}$ and $\mathrm{MCl}-1$ were analyzed by Western blot in four HCC cell lines, taking a-tubulin as a loading control. (B) HCC cells were treated with $5 \mu$ M ABT-263 for $18 \mathrm{~h}$, then the expression levels of $\mathrm{MCl}-1, \mathrm{BCl}-2$ and $\mathrm{BCl}-\mathrm{xL}$ were analyzed by Western blot. (C) Hep3B and Huh7 cells were transfected with either BCl-2 siRNA (or control siRNA) or pcDNA3-BCl-2 plasmid (or control plasmid pcDNA3.0) for 36 h, then the level of Mcl-1 was analyzed by Western blot. (D) Hep3B and Huh7 cells were transfected with control siRNA or Mcl-1 siRNA for $36 \mathrm{~h}$, then Mcl-1 protein level was analyzed by Western blot. (E) After transfected with Mcl-1 siRNA or control siRNA for $24 \mathrm{~h}$, the HCC cells were treated with $5 \mu \mathrm{M}$ ABT-263 or vehicle DMSO for another $36 \mathrm{~h}$. Then the cell viability was analyzed by CCK-8 kit. Data were expressed as the mean \pm SD from three independent experiments. ${ }^{*}: P<0.05$; ***: $P<0.0001$ ). 
of Bcl-2 and Bcl-xL differed. Hep3B cells had low level of Bcl-xL and Huh7 cells had almost no detectable Bcl-2. Upon treatment with ABT-263, the level of Mcl-1 increased dramatically in all HCC cell lines, but the levels of $\mathrm{Bcl}-2$ and $\mathrm{Bcl}-\mathrm{xL}$ did not change significantly (Figure 1B). Another Bcl-2 inhibitor AT-101 had similar effect on Mcl1 expression in HCC cells (Additional file 1: Figure S1). To test whether the upregulation of $\mathrm{Mcl}-1$ is affected by Bcl-2 level, we knocked down Bcl-2 in Hep3B cells and overexpressed it in Huh7 cells, respectively. As shown in Figure $1 \mathrm{C}$, the level of Mcl-1 remained unchanged upon Bcl-2 downregulation or overexpression. Similar results were also found when Bcl-xL was knocked down in Huh7 cells or overexpressed in Hep3B cells (date not shown). These results indicated that ABT-263-induced Mcl-1 upregulation was independent of the levels of $\mathrm{Bcl}-2 / \mathrm{xL}$ in HCC cells. Furthermore, consistent with previous reports [19-21], Mcl-1 knockdown significantly enhanced the cytotoxicity of ABT-263 in HCC cells (Figure 1D and E). The above data indicated that the drug resistance of ABT263 was, at least partially, mediated by Mcl-1 upregulation, which was not associated with the expression levels of $\mathrm{Bcl}-2 / \mathrm{xL}$ in $\mathrm{HCC}$ cells.

\section{ABT-263 upregulates Mcl-1 at both mRNA and protein levels}

To investigate the underlying mechanism of ABT-263induced Mcl-1 upregulation in HCC cells, both mRNA and protein levels of $\mathrm{Mcl}-1$ were analyzed after treatment with ABT-263. Since PLC and Huh7 cell lines had a higher sensitivity to ABT-263 after Mcl-1 knockdown (Figure 1E), they were chosen as target cells. As shown in Figure 2, ABT-263 upregulated Mcl-1 at both mRNA and protein levels in PLC and Huh7 cells revealed by RT-PCR (Figure 2A), real-time PCR (Figure 2B) and Western blot (Figure 2C).

\section{ABT-263 increases the mRNA stability of Mcl-1}

To figure out the mechanisms of ABT-263-mediated Mcl-1 mRNA upregulation, the promoter region of Mcl1 gene ( -3009 to +251 , named M1) was cloned into reporter vector pGL3-basic, and the resulting plasmid was named as pLucM1 (Figure 3A). Meanwhile, the promoter region $(-607$ to +251 , named M2) containing the binding sites for several predicted transcriptional factors was also cloned into pGL3-basic, and the resulting plasmid was named as pLucM2 (Figure 3A). Then PLC and Huh7 cells were separately transfected with pLucM1 and pLucM2 and followed by the treatment with ABT-263. As shown in Figure 3B, ABT-263 didn't affect the activity of Mcl-1 promoter in HCC cells, neither in pLucM1 nor in pLucM2. Subsequently, PLC and Huh7 cells were treated with transcription inhibitor actinomycin D (Act $D)$ in the presence or absence of ABT-263. As shown in Figure 3C, ABT-263 co-treatment significantly enhanced the mRNA stability of Mcl-1 compared to Act D treatment alone $(p<0.05)$. These results indicated that ABT263 upregulated Mcl-1 mRNA level via increasing the mRNA stability instead of activating its transcription in HCC cells.

\section{A}

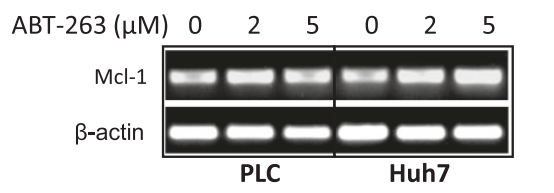

\begin{tabular}{lllllll} 
Time (h) & 0 & 12 & 24 & 0 & 12 & 24 \\
\hline
\end{tabular}

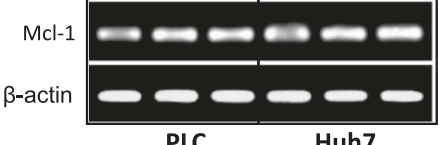

PLC

C

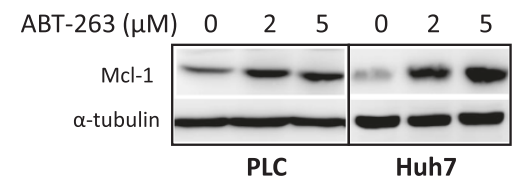

B
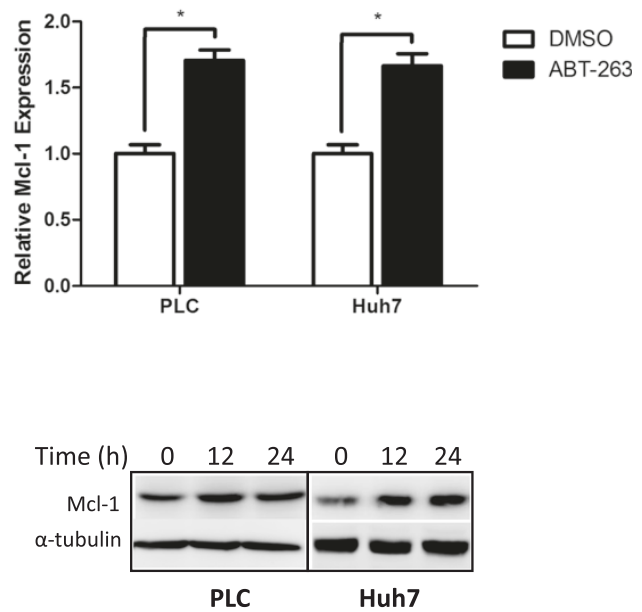

Figure 2 ABT-263 upregulates Mcl-1 at both mRNA and protein levels. (A) PLC and Huh7 cells were treated with various doses of ABT-263 for $24 \mathrm{~h}$ or with $5 \mu \mathrm{M}$ ABT-263 for indicated times. Then RT-PCR was performed to detect the level of Mcl-1 mRNA, taking $\beta$-actin as a control. (B) HCC cells were treated with $5 \mu \mathrm{M}$ ABT-263 or vehicle DMSO for $24 \mathrm{~h}$, then qPCR was performed to quantitate Mcl-1 mRNA, taking $\beta$-actin as a control. Data were represented as mean \pm SD from three independent experiments. (*: $P<0.05)$. (C) HCC cells were treated as described in (A), then the level of Mcl-1 was analyzed by Western blot, taking a-tubulin as a loading control. 


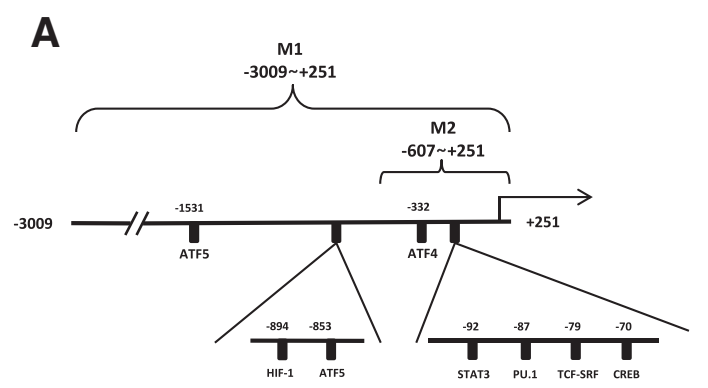

Promoter region of $\mathrm{Mcl}-1$
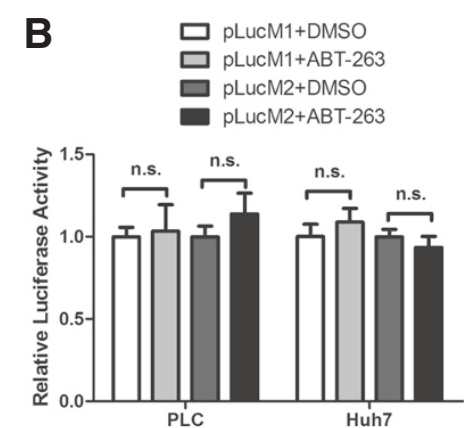

\section{C}
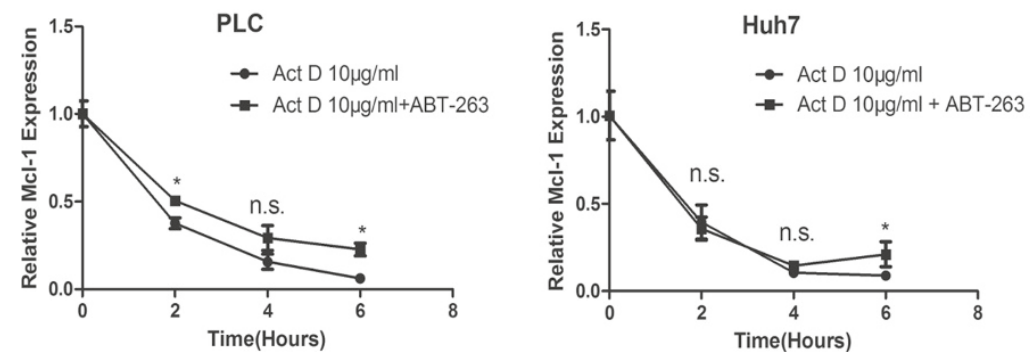

Figure 3 ABT-263 increases the mRNA stability of Mcl-1. (A) Schematic representation of Mcl-1 promoter region containing several transcription factor binding sites. Two fragments ( -3009 to +251 and -607 to +251 ) were separately amplified from genomic DNA of HepG2 cells and inserted into pGL3-basic vector, and the resulting plasmids were named as pLucM1 and pLuCM2 respectively. (B) After Co-transfected with pLucM1 or pLucM2 and pCMV- $\beta$-gal plasmid for $12 \mathrm{~h}$, the HCC cells were treated with $5 \mu \mathrm{M}$ ABT-263 or vehicle DMSO for another $24 \mathrm{~h}$. Then the luciferase assay was performed. Data were expressed as mean \pm SD from three independent experiments. (C) HCC cells were treated with $10 \mu \mathrm{gg} / \mathrm{ml}$ actinomycin $\mathrm{D}$ (Act D) in the presence or absence of $5 \mu \mathrm{M}$ ABT-263 for indicated times, then the level of Mcl-1 mRNA was quantified by qPCR, taking $\beta$-actin as a control. Data were represented as mean \pm SD from three independent experiments. (*: $P<0.05)$.

\section{ABT-263 increases the protein stability of $\mathrm{Mcl}-1$}

To assess whether the increase of $\mathrm{Mcl}-1$ protein solely results from the upregulation of Mcl-1 mRNA, the HCC cells were treated with translation inhibitor cycloheximide (CHX). As shown in Figure 4A and B, the level of Mcl-1 protein decreased dramatically after treatment with $\mathrm{CHX}$ alone, and the half-life of $\mathrm{Mcl}-1$ protein was 30 min. Co-treatment with ABT-263 and CHX markedly attenuated the degradation of $\mathrm{Mcl}-1$ protein, and the half-life of Mcl-1 protein reached to more than $4 \mathrm{~h}$. These results indicated that ABT-263 enhanced Mcl-1 protein stabilization in HCC cells. Meanwhile, ABT-263 could not further upregulate Mcl-1 protein level after proteasome was inhibited by MG132, suggesting that ABT-263 might upregulate Mcl-1 protein level by decreasing proteasome-mediated degradation (Figure $4 \mathrm{C}$ ). As to whether ABT-263 affected the ubiquitinationmediated Mcl-1 degradation, the role of deubiquitinase USP9X (ubiquitin-specific peptidase 9, X-linked) was investigated. As shown in Figure 4D and E, knockdown of USP9X didn't affect ABT-263-mediated Mcl-1 accumulation, indicating that USP9X-mediated deubiquitination doesn't contribute to ABT-263-enhanced Mcl-1 stability.

\section{Activation of ERK and JNK involves in ABT-263-induced stabilization of $\mathrm{Mcl}-1$ protein}

It is known that there is a unique PEST region in Mcl-1 protein and the phosphorylation of this region is closely associated with $\mathrm{Mcl}-1$ protein stability [22], so we analyzed the activity of several kinases which directly phosphorylate Mcl-1, including extracellular regulated kinase (ERK) and c-Jun terminal kinase (JNK). Meanwhile, phosphorylation of mammalian target of rapamycin (mTOR) was also detected upon ABT-263 treatment since its activation through phosphorylation can regulate the translational process of $\mathrm{Mcl}-1$ protein [23]. As shown in Figure 5A, ERK and JNK were activated while mTOR was repressed after treatment with ABT-263. To further clarify the role of these kinases in ABT-263-enhanced Mcl-1 protein stabilization, their inhibitors were used. ERK inhibitor U0126 and JNK inhibitor SP600125, but not mTOR inhibitor rapamycin, markedly attenuated ABT-263-caused Mcl-1 upregulation (Figure 5B). Moreover, ERK and JNK inhibitors significantly increased ABT-263-induced apoptosis in PLC and Huh7 cells revealed by annexin V-FITC/ PI staining flow cytometry analysis (Figure 5C), trypan blue exclusion assay (Figure 5D) and Western blot for enhanced PARP cleavage (Figure 5E and F). These results 


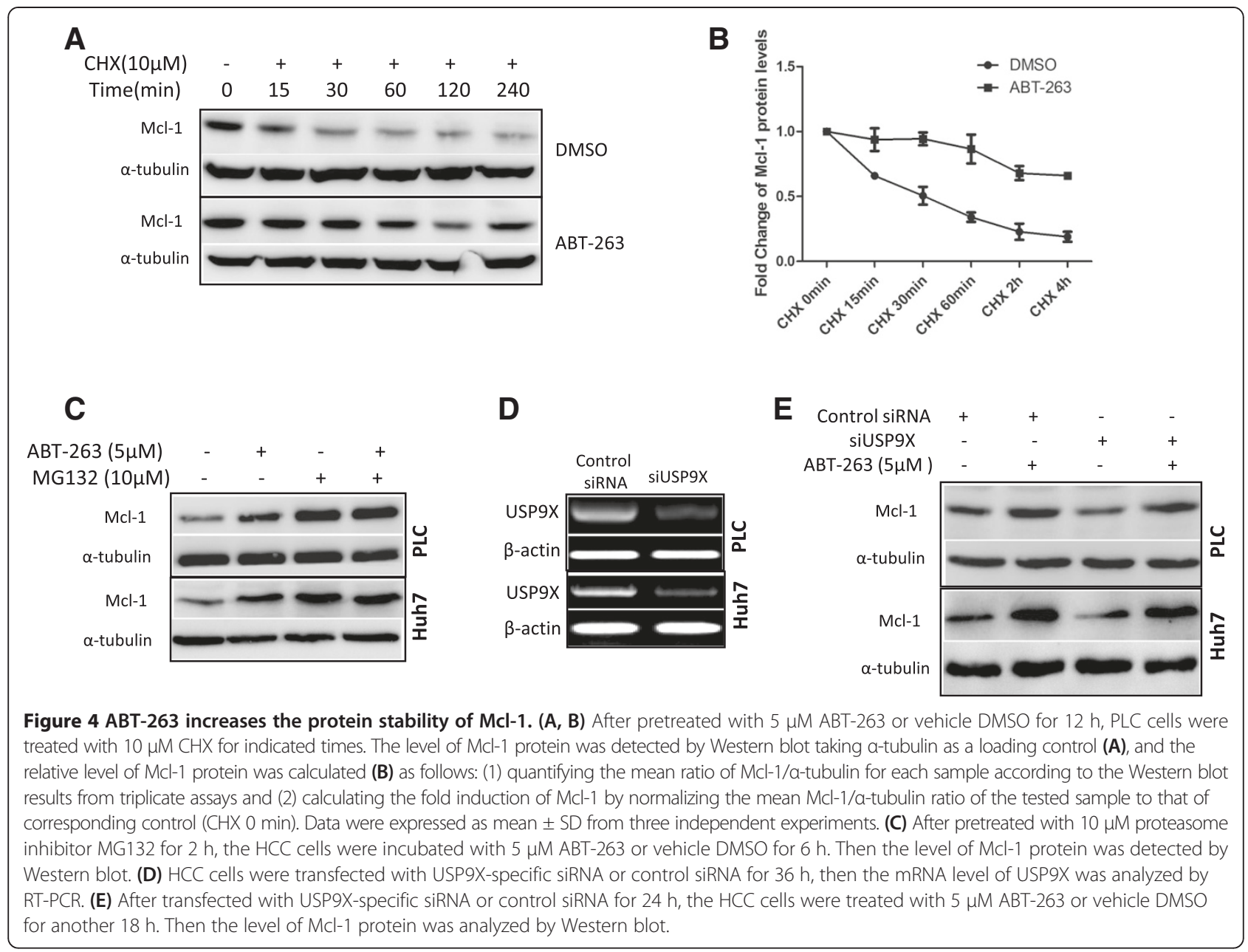

indicated that activation of ERK and JNK, but not mTOR, involved in ABT-263-mediated Mcl-1 protein stabilization and drug resistance.

\section{ABT-263 enhances ERK- and JNK-mediated Mcl-1 ${ }^{\text {Thr163 }}$ phosphorylation}

To further investigate the concrete mechanisms of ERKand JNK-mediated Mcl-1 stabilization, the phosphorylation status of $\mathrm{Mcl}-1^{\text {Thr163 }}$ was analyzed. As shown in Figure $5 \mathrm{E}$ and $\mathrm{F}$, inhibition of ERK or JNK significantly attenuated ABT-263-induced $\mathrm{Mcl}-1^{\text {Thr163 }}$ phosphorylation and Mcl-1 accumulation, suggesting that the phosphorylation of Mcl-1 ${ }^{\text {Thr163 }}$ may contribute to ERK- and JNK-mediated Mcl-1 stabilization upon ABT-263 treatment in HCC cells.

\section{Akt-mediated GSK-3 $\beta$ inactivation also involves in ABT-263-induced Mcl-1 stabilization}

Since Serine ${ }^{159}$ is also closely related with Mcl-1 stability and this site is mainly phosphorylated by GSK-3 $\beta$ [24], we tested whether GSK-3 $\beta$ involves in ABT-263-induced Mcl-1 stabilization in HCC cells. As shown in Figure 6A,
ABT-263 increased the phosphorylation of GSK-3 $\beta$, but no effect on total GSK-3ß. Meanwhile, ABT-263 enhanced the phosphorylation of Akt, an upstream signal molecule of GSK-3 $\beta$. Suppression of Akt by its inhibitor BEZ-235 dramatically attenuated ABT-263-mediated GSK-3 $\beta$ phosphorylation, Mcl-1 upregulation and apoptosis resistance (Figure 6B). Subsequently, we checked whether the phosphorylation of GSK-3 $\beta$ is also affected by ERK, another upstream regulator of GSK-3 $\beta$. As shown in Figure 6C, inhibition of ERK with U0126 had no effect on ABT-263-triggered GSK-3 $\beta$ phosphorylation, indicating that GSK-3 $\beta$ activity was not regulated by ERK in this process. Furthermore, Akt inhibitor also increased the cytotoxicity of ABT-263 in HCC cells (Figure 6D). These results indicated that Akt-mediated GSK-3 $\beta$ inactivation also involves in ABT-263-induced Mcl-1 stabilization, possibly through regulating the phosphorylation of $\mathrm{Mcl}-1^{\text {Ser159 }}$.

\section{Discussion}

In the present study, we demonstrated that ABT-263 upregulated $\mathrm{Mcl}-1$ by increasing the stability of $\mathrm{Mcl}-1$ 


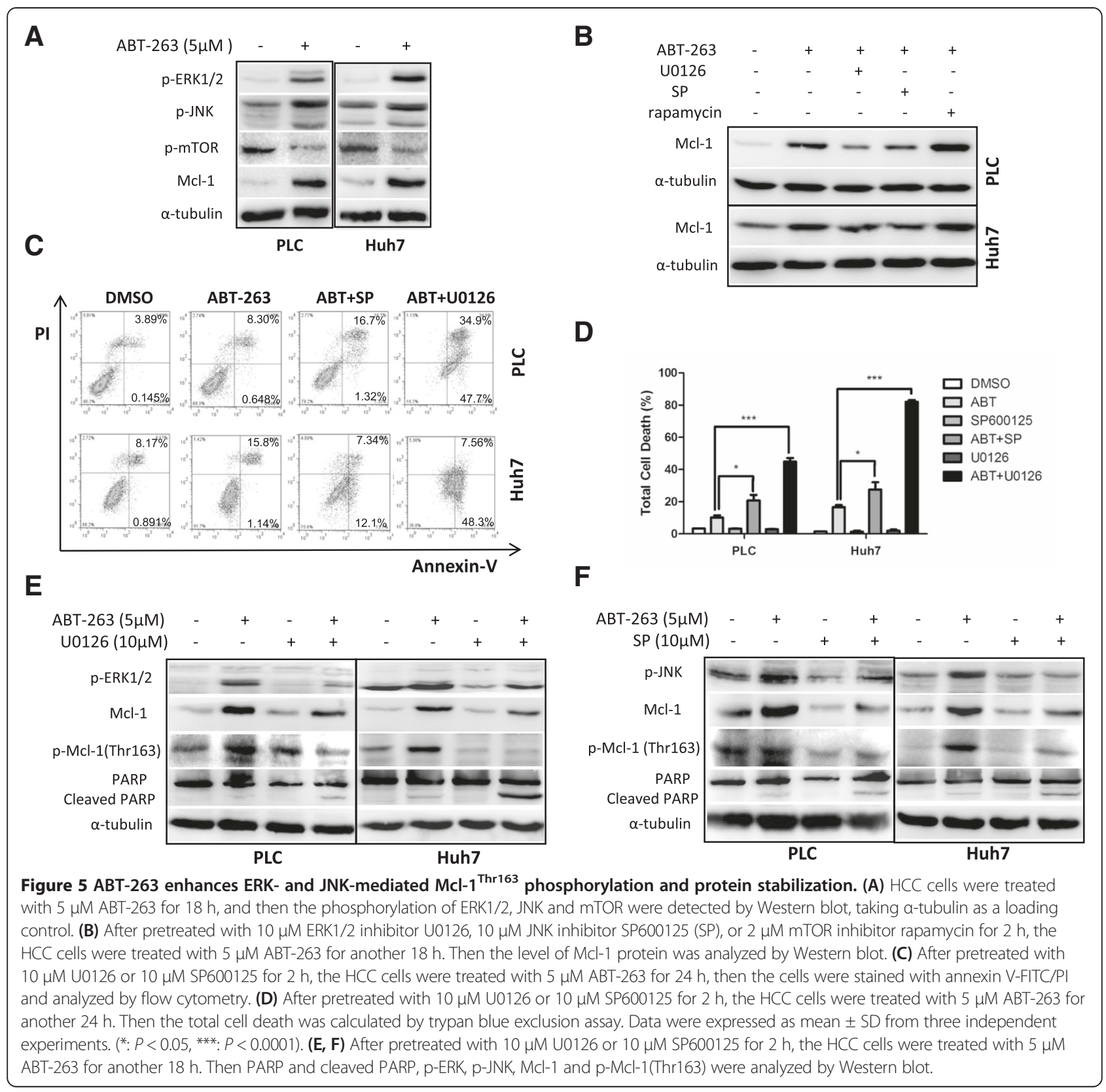

mRNA and protein in HCC cells. As shown in the working model (Figure 7), ABT-263 increased Mcl-1 mRNA level by augmenting its stability instead of transcriptional activation. Meanwhile, ABT-263 enhanced Mcl-1 protein stability by regulating the phosphorylation status of Mcl-1. ERK- and JNK-mediated Mcl-1 ${ }^{\text {Thr163 }}$ phosphorylation contributed to ABT-263-induced Mcl-1 protein stability. Akt-mediated GSK-3 $\beta$ inactivation also played important role in preventing $\mathrm{Mcl}-1$ protein degradation in the presence of ABT-263.

ABT-263, a newly-developed, oral-tolerant Bcl-2/xL inhibitor, has shown promising anti-tumor efficacy in nonsmall cell lung cancer and acute lymphoblastic leukemia as single agent both in vitro and in vivo [25]. Meanwhile, ABT-263 can markedly sensitize several clinical drugs in cancer therapy [26,27]. However, a recent study has demonstrated that $\mathrm{HCC}$ cells are relatively resistant to ABT737 (analog of ABT-263) compared to leukemia and lung carcinomas [28]. Furthermore, it has been indicated that ABT-737-induced Mcl-1 upregulation contributes to this resistance [14]. Consistent with ABT-737, our results showed that both ABT-263 and another Bcl-2 inhibitor AT-101 upregulated Mcl-1 in HCC cells, which at last resulted in drug resistance. So it is important to clarify the associated mechanisms of ABT-263-induced Mcl-1 upregulation in HCC cells. 

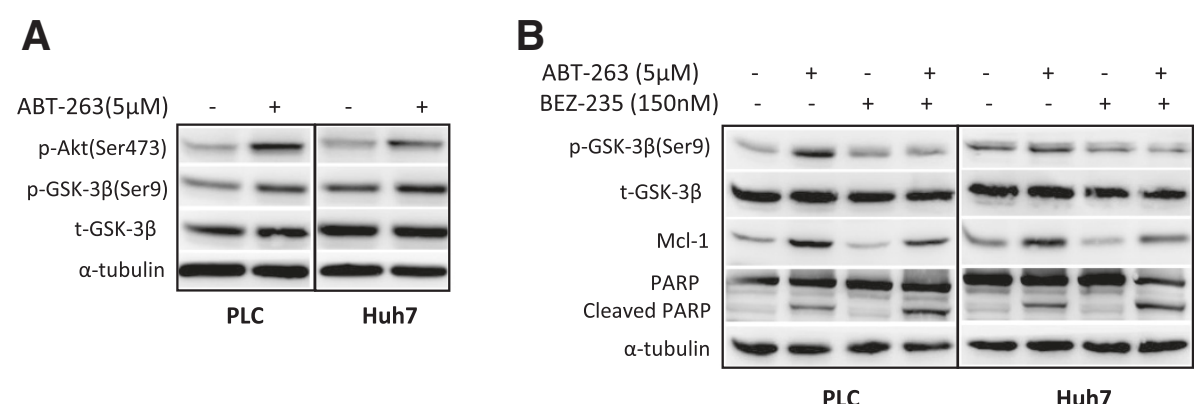

C

\section{D}

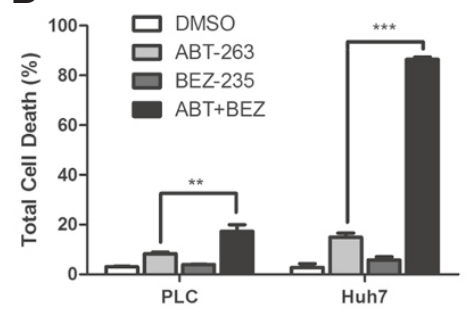

Figure 6 Akt-mediated GSK-3 $\beta$ inactivation also involves in ABT-263-induced stabilization of Mcl-1 protein. (A) HCC cells were treated

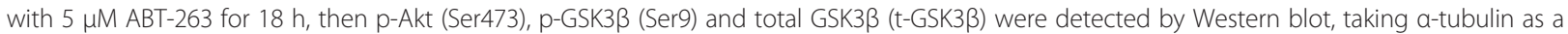
loading control. (B) After pretreated with 150nM PI3K/mTOR dual inhibitor NVP-BEZ235 for $2 \mathrm{~h}$, the HCC cells were treated with $5 \mu \mathrm{M}$ ABT-263 for $18 \mathrm{~h}$. Then p-GSK3 $\beta$ (Ser9) and t-GSK3 $\beta$, Mcl-1, PARP and cleaved PARP were analyzed by Western blot. (C) After pretreated with $10 \mu \mathrm{M}$ ERK1/2 inhibitor U0126 for $2 \mathrm{~h}$, the HCC cells were treated with $5 \mu \mathrm{M}$ ABT-263 for $18 \mathrm{~h}$. Then p-GSK3 3 (Ser9) and t-GSK3 $\beta$ were detected by Western blot. (D) After pretreated with 150nM NVP-BEZ235 for $2 \mathrm{~h}$, the HCC cells were treated with $5 \mu \mathrm{M}$ ABT-263 for another $24 \mathrm{~h}$. Then the total cell death was analyzed by trypan blue exclusion assay. Data were expressed as mean \pm SD from three independent experiments. $\left(*^{* *}: P<0.01, * * *: P<0.0001\right)$.

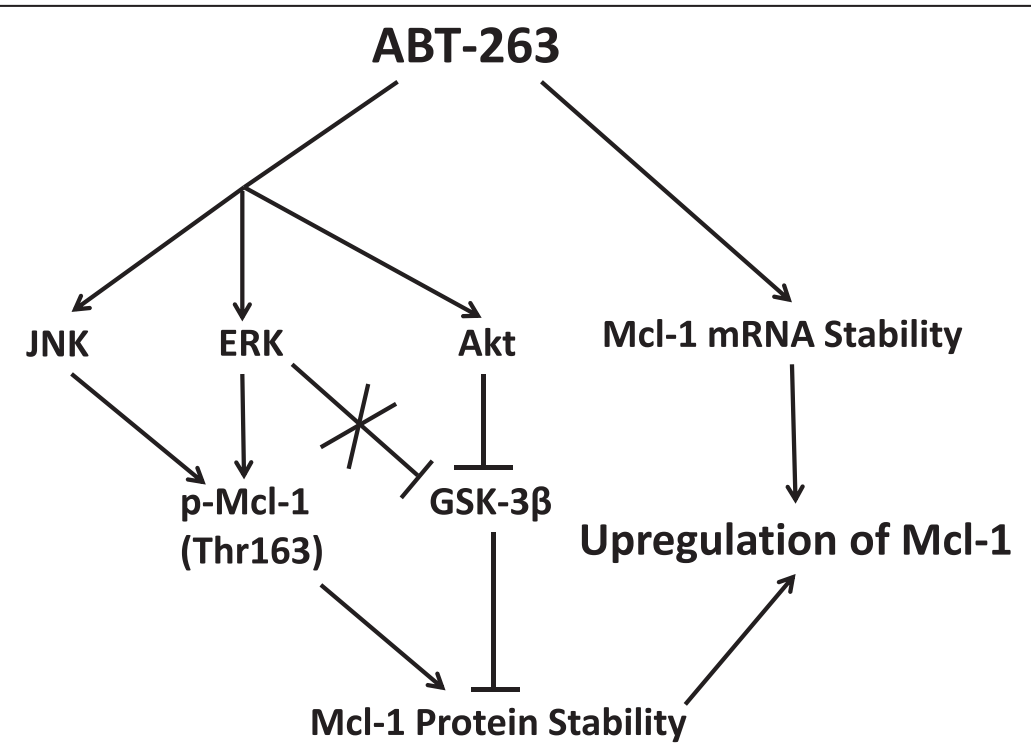

Figure 7 Schematic illustration for the action mechanisms of ABT-263-induced Mcl-1 upregulation in HCC cells. ABT-263 increases MCl-1 mRNA level by augmenting its stability instead of transcriptional activation. Meanwhile, ABT-263 enhances Mcl-1 protein stability by regulating the phosphorylation status of MCl-1. ERK- and JNK-mediated MCl-1 ${ }^{\text {Thr163 }}$ phosphorylation contribute to ABT-263-induced Mcl-1 protein stability. Akt-mediated GSK-3 $\beta$ inactivation also plays important role in preventing Mcl-1 protein degradation in the presence of ABT-263. By increasing Mcl-1 stability at both mRNA and protein levels, ABT-263 induces Mcl-1 upregulation. 
It is known that Mcl-1 is an important anti-apoptotic protein, which is now becoming a quite important target for cancer therapy [29]. Characteristically, it has a short half-life and is elaborately regulated at different levels [17]. We found that ABT-263 increased Mcl-1 mRNA level in HCC cells. It is also reported that Mcl-1 can be regulated by several transcription factors, including STAT3 [30], ATF4 [31], CREB [32] and HIF-1 [33]. However, the luciferase assay results in this study demonstrated that ABT-263 did not increase the transcriptional activity of $\mathrm{Mcl}-1$ promoter, indicating that these transcription factors may not play dominated roles in this process. Furthermore, we demonstrated that ABT263 enhanced Mcl-1 mRNA stability in HCC cells. It is known that RNA stability is affected by various factors such as RNases and RNA binding proteins, but just only one RNA binding protein CUGBP2 has been reported to play a role in Mcl-1 mRNA stabilization [34]. Therefore, it is unclear at present whether ABT-263-enhanced Mcl1 mRNA stability is associated with CUGBP2, which is interesting and needs further studies.

Besides mRNA level, protein stability also plays important role in the upregulation of $\mathrm{Mcl}-1$ protein. It is known that the phosphorylation of Mcl-1 is closely associated with Mcl-1 protein stabilization [22]. Serine ${ }^{159}$ and Threonine ${ }^{163}$ are two important phosphorylation sites in Mcl-1 PEST region to determine the fate of Mcl1 degradation. Mcl-1 can be phosphorylated by ERK at its $\mathrm{Thr}^{163}$ site, which prolongs the half life of this protein [35]. ERK mediated-phosphorylation at $\mathrm{Thr}^{163}$ represents an important resistant mechanism in leukemia cells [15] and the inhibition of MEK/ERK sensitizes the anti-tumor effect of ABT-737 [36]. Consistent with these reports, our study showed that ERK-mediated $\mathrm{Thr}^{163}$ phosphorylation of Mcl-1 contributed to ABT-263 resistance in HCC cells. JNK, another important member of MAPK family, can phosphorylate Mcl-1 at several sites, but the effect of JNK on Mcl-1 is varied [22]. JNKmediated $\mathrm{Thr}^{163}$ phosphorylation may lead to enhanced Mcl-1 degradation [37] or increased Mcl-1 stabilization [38]. Our data demonstrated that ABT-263 increased JNKmediated Mcl-1 ${ }^{\text {Thr163 }}$ phosphorylation, which enhanced Mcl-1 protein stability in HCC cells. Furthermore, both ERK and JNK inhibitors sensitized ABT-263-induced apoptosis and cell death by downregulating Mcl-1 in HCC cells, which may be novel ways to sensitize ABT-263 in HCC therapy.

GSK-3 $\beta$ plays an important role in glucose metabolism in mammalian cells. After being phosphorylated at Serine $^{9}$, GSK-3 $\beta$ loses its activity. It is known that Mcl-1 can be phosphorylated by GSK-3 $\beta$ at $\operatorname{Ser}^{159}$ site, which decreases Mcl-1 stability [24]. A recent study has shown that ABT-263 enhances the anti-tumor effect of PI3K inhibitor in GSK3-dependent manner in human myeloid leukemia cells, but the detailed mechanisms are still not clear [39]. Our study demonstrated that ABT-263 promoted GSK-3 $\beta$ inactivation and Mcl-1 stability via Akt pathway, indicating that inhibition of Akt may be a good strategy to sensitize ABT-263 in HCC treatment.

It is well known that $\mathrm{Bcl}-2 / \mathrm{xL}$ are involved in regulating the homeostasis of apoptosis, autophagy and oxidative stress in the cells [40], which are associated with ERK, JNK and Akt pathways. ABT-263 is known as a specific inhibitor of $\mathrm{Bcl}-2 / \mathrm{xL}$, so the mechanisms by which ABT-263 activates ERK, JNK and Akt may be complicated. Our previous data have shown that $\mathrm{Bcl}-2$ inhibitor apogossypolone can induce reactive oxygen species (ROS) in HCC cells, which results in the activation of multiple vital signaling pathways including ERK, JNK and Akt pathways [41]. In the present study, we demonstrated that ABT-263 could induce the phosphorylations of ERK, JNK and Akt, which were markedly attenuated by the widely used antioxidant $\mathrm{N}$-acetyl-cysteine (Additional file 1: Figure S2), suggesting that ABT-263 may activates ERK, JNK and Akt via, at least partially, inducing ROS production.

\section{Conclusions}

In conclusion, our study demonstrates that ABT-263 upregulates Mcl-1 through increasing its mRNA and protein stability, which contributes to the resistance of ABT-263 in HCC cells. Inhibition of ERK-, JNK- or Aktmediated Mcl-1 stability may confer Bcl-2 inhibitor better anti-tumor effect in HCC cells. Our results may provide more details to $\mathrm{Bcl}$-2-targeted therapeutics and give insights into the future clinical trials of Bcl-2 inhibitors in HCC therapy.

\section{Materials and methods Materials}

The cell culture reagents were purchased from Hyclone (Waltham, MA, USA). ABT-263, cycloheximide, SP600125, rapamycin, NVP-BEZ235 and N-acetyl-cysteine were purchased from Sigma-Aldrich (Louis, MO, USA). U0126, Act D, MG132, the antibody against $\alpha$-tubulin, BCA protein assay kit and RIPA lysis buffer were purchased from Beyotime Biotechnology (Shanghai, China). AnnexinVFITC/propidium iodide (PI) apoptosis detection kit was purchased from BD bioscience (BD, NJ, USA). Cell Counting Kit-8 (CCK-8) was from Dojindo (Shanghai, China). Trizol agent, M-MLV transcriptase and Lipofectamin 2000 were from Invitrogen (Carlsbad, CA, USA). SYBR qPCR master mix, PrimeSTAR HS DNA polymerase, restriction endonuclease NheIand HindIII were from TAKARA (Shiga, Japan). pGL3-basic vector, pCMV- $\beta$-gal plasmid, luciferase assay and $\beta$-gal assay systems were from Promega (Madison, WI, USA). Antibodies of $\mathrm{Mcl}-1$ and Bcl-2 were purchased from Santa Cruz Biotechnology (Santa 
Cruz, CA, USA). Antibodies separately against Bcl-xL, PARP, phosphorylated ERK1/2 (p-ERK1/2, Thr202/Tyr204), total-ERK, p-JNK(Thr183/Tyr185), p-mTOR(Ser2448), p-Mcl-1(Thr163), p-Akt(Ser473), p-GSK-3ß(Ser9) and total-GSK-3 $\beta$ were from Cell Signaling Technology (Boston, MA, USA). HRP-conjugated goat anti-rabbit and anti-mouse IgG were purchased from Zhongshan Company (Beijing, China). siRNAs to Bcl-2, Bcl-xL, USP9X and control siRNAs were from Dharmacon (Lafayette, CO, USA). pcDNA3-Bcl-2 and pcDNA3-Bcl$\mathrm{xL}$ expression plasmids were kindly gifts from University of Michigan( pcDNA3.0 was used as negative control).

\section{Cell culture}

Human HCC cell lines PLC/PRF/5, HepG2, Huh7 and Hep3B were purchased from American Type Culture Collection (ATCC), and cultured in high-glucose DMEM (Dulbecco's modified Eagle's medium) with 10\% FBS (fetal bovine serum), streptomycin $(100 \mu \mathrm{g} / \mathrm{mL})$ and penicillin $(100 \mathrm{U} / \mathrm{mL})$. These cell lines were originally tested by ATCC and passaged less than 6 months in the lab.

\section{Quantitative polymerase chain reaction (qPCR)}

After treatment, the cells were lysed and total RNA was extracted with Trizol agent as described [42], and firststrand cDNA was synthesized using M-MLV transcriptase. qPCR was performed to detect the level of Mcl-1 mRNA using SYBR qPCR master mix in a $25 \mu$ l volume according to the manufacturer's instruction. The sequences of different primers were as follows: $\mathrm{Mcl}-1$ : forward primer 5'-AAAGCCTGTCTGCCAAAT-3' and reverse primer 5' CCTATAAACCCACCACTC-3'; USP9X: forward primer 5' -CCTGCTGGTGCACCTCTGGC-3' and reverse primer 5' -AGGCCGGTGTCCCATGCAA-3'; $\beta$-actin: forward primer 5'-ATCGTGCGTGACATTAAGGAGAAG-3' and reverse primer 5 '-AGGAAGGAAGGCTGGAAGA GTG-3'.

\section{Western blot}

After treatment, the cells were harvested and whole-cell lysates were prepared. The protein concentrations were measured by BCA protein assay kit. Subsequently, Western blot analysis was performed as described [41].

\section{Transfection of siRNA and $\mathrm{Bcl}-2 / \mathrm{xL}$ expression plasmid}

The HCC cells were separately transfected with siRNAs to Bcl-2 (or Bcl-xL or USP9X) and control siRNA using Lipofectamine 2000 according to the manufacturer's instruction. Similarly, the expression plasmid pcDNA3-Bcl-2 or pcDNA3-Bcl-xL was transfected into the corresponding $\mathrm{HCC}$ cells, taking pcDNA3.0 as negative control.

\section{Cell viability assay}

Cell viability assay was performed by using Cell Counting Kit-8 (CCK-8). Briefly, cells were seeded in triplicate in 96-well plates and given different treatments for indicated time, then the OD value at $450 \mathrm{~nm}$ was detected according to the manufacturer's instruction.

\section{Plasmid construction}

Human Mcl-1 promoter regions -3009 to $+251(\mathrm{M} 1)$ and -607 to $+251(\mathrm{M} 2)$ were amplified by PCR using PrimeSTAR HS DNA polymerase taking genomic DNA of HepG2 cells as template. The two PCR fragments were separately inserted into pGL3-basic vector after digestion with restriction endonucleases NheI and HindIII, and the resulting plasmids were named as pLucM1 and pLucM2, respectively.

\section{Luciferase reporter assay}

PLC and Huh7 cells were seeded in 48-well plates and were co-transfected with pLucM1 or pLucM2 and monitor plasmid pCMV- $\beta$-gal using Lipofectamin 2000 according to the manufacturer's protocol. After $36 \mathrm{~h}$, the cells were lysed, and luciferase activity and $\beta$-gal activity were separately detected using Promega luciferase and $\beta$-gal assay systems according to the manufacturer's protocols. The luciferase activity was normalized against $\beta$-gal activity. The transfection experiments were performed at least three times in triplicate. Data were represented as fold induction by normalizing the luciferase activity of the tested sample to that of the corresponding control sample.

\section{Trypan blue exclusion assay}

The trypan blue exclusion assay was performed as described [41]. The total death rate $(\%)=$ numbers of dead cells/(numbers of living cells + numbers of dead cells) $\times 100$.

\section{Flow cytometry}

After treatment, the HCC cells were harvested and incubated with annexin V-FITC and PI according to the manufacturer's instructions. Then the apoptosis were analyzed by a flow cytometer.

\section{Statistic analysis}

The data were expressed as Mean \pm SD. Two-way $t$-test and ANOVA were used to analyze the variance. $P<0.05$ was defined as statistically significant.

\section{Additional file}

Additional file 1: Figure S1. BCl-2 inhibitor AT-101 upregulates $\mathrm{Mcl}-1$ in four HCC cell lines. HCC cells were treated with 10 MM AT-101 or vehicle DMSO for $18 \mathrm{~h}$, then the protein level of $\mathrm{Mcl}-1$ was analyzed by Western blot, taking a-tubulin as a loading control. Figure S2. N-acetyl-L-cysteine 
dramatically attenuates ABT-263-induced $\mathrm{Mcl}-1$ upregulation and phophorylation of ERK, JNK and Akt. After pretreated with $10 \mathrm{mM}$ $\mathrm{N}$-acetyl-cysteine (NAC) for $2 \mathrm{~h}$, the HCC cells were treated with $5 \mu \mathrm{M}$ ABT-263 or vehicle DMSO for another $18 \mathrm{~h}$. Then Mcl-1, p-ERK, p-JNK and $\mathrm{p}$-Akt were detected by Western blot, taking a-tubulin as a loading control.

\section{Competing interests}

The authors declare that they have no competing interests.

\section{Authors' contributions}

BW and Z-HN mainly performed the Western blot tests, data collection, data analysis and the draft of this manuscript. X-FD and L-YQ mainly performed the functional assays. $X$-ZL performed the luciferase assays. $L X$ contributed to the discussion section and interpretation of some results. J-QL and F-TH contributed to the study design and the manuscript revision. All authors read and approved the final manuscript.

\section{Acknowledgments}

This study was supported in part by Chongqing Natural Science Foundation (cstc2011BB5030 and 2013jjB10015), the National Natural Science Foundation of China $(31201068,81273226$ and 81228005) and the Scientific Funds of Third Military Medical University (2011XHG02 and 2012XZH01).

\section{Author details}

${ }^{1}$ Department of Biochemistry and Molecular Biology, College of Basic Medical Sciences, Third Military Medical University, 30 Gaotanyan, Chongqing 400038, China. ${ }^{2}$ Department of Educational Science College, Chongqing Normal University, Chongqing 400038, China. ${ }^{3}$ Departments of Molecular Biosciences and Radiation Oncology, University of Kansas Cancer Center, University of Kansas, Lawrence 66045-7534, USA.

Received: 25 October 2013 Accepted: 24 April 2014 Published: 30 April 2014

\section{References}

1. El-Serag HB, Rudolph KL: Hepatocellular carcinoma: epidemiology and molecular carcinogenesis. Gastroenterology 2007, 132:2557-2576.

2. Tanaka S, Arii S: Molecular targeted therapies in hepatocellular carcinoma. Semin Oncol 2012, 39:486-492.

3. Zender L, Spector MS, Xue W, Flemming P, Cordon-Cardo C, Silke J, Fan ST, Luk JM, Wigler M, Hannon GJ, Mu D, Lucito R, Powers S, Lowe SW: Identification and validation of oncogenes in liver cancer using an integrative oncogenomic approach. Cell 2006, 125:1253-1267.

4. Lessene G, Czabotar PE, Colman PM: BCL-2 family antagonists for cancer therapy. Nat Rev Drug Discov 2008, 7:989-1000.

5. Yang TM, Barbone D, Fennell DA, Broaddus VC: Bcl-2 family proteins contribute to apoptotic resistance in lung cancer multicellular spheroids. Am J Respir Cell Mol Biol 2009, 41:14-23.

6. Tabuchi Y, Matsuoka J, Gunduz M, Imada T, Ono R, Ito M, Motoki T, Yamatsuji T, Shirakawa Y, Takaoka M, Haisa M, Tanaka N, Kurebayashi J, Jordan VC, Naomoto Y: Resistance to paclitaxel therapy is related with $\mathrm{Bcl}-2$ expression through an estrogen receptor mediated pathway in breast cancer. Int J Oncol 2009, 34:313-319.

7. Cho HJ, Kim JK, Kim KD, Yoon HK, Cho MY, Park YP, Jeon JH, Lee ES, Byun SS, Lim HM, Song EY, Lim JS, Yoon DY, Lee HG, Choe YK: Upregulation of BCl-2 is associated with cisplatin-resistance via inhibition of Bax translocation in human bladder cancer cells. Cancer Lett 2006, 237:56-66.

8. Sartorius UA, Krammer $\mathrm{PH}$ : Upregulation of $\mathrm{BCl}-2$ is involved in the mediation of chemotherapy resistance in human small cell lung cancer cell lines. Int J Cancer 2002, 97:584-592.

9. Yang Y, Zhu J, Gou H, Cao D, Jiang M, Hou M: Clinical significance of Cox-2, Survivin and BCl-2 expression in hepatocellular carcinoma (HCC). Med Oncol 2011, 28:796-803.

10. Chun $\mathrm{E}$, Lee $\mathrm{KY}: \mathrm{BCl}-2$ and $\mathrm{BCl}-\mathrm{xL}$ are important for the induction of paclitaxel resistance in human hepatocellular carcinoma cells. Biochem Biophys Res Commun 2004, 315:771-779.

11. Davids MS, Letai A: Targeting the B-cell lymphoma/leukemia 2 family in cancer. J Clin Oncol 2012, 30:3127-3135.
12. Gandhi L, Camidge DR, Ribeiro de Oliveira M, Bonomi P, Gandara D, Khaira D, Hann CL, McKeegan EM, Litvinovich E, Hemken PM, Dive C, Enschede SH, Nolan C, Chiu YL, Busman T, Xiong H, Krivoshik AP, Humerickhouse R, Shapiro Gl, Rudin CM: Phase I study of Navitoclax (ABT-263), a novel $\mathrm{Bcl}-2$ family inhibitor, in patients with small-cell lung cancer and other solid tumors. J Clin Oncol 2011, 29:909-916.

13. Rudin CM, Hann CL, Garon EB, Ribeiro de Oliveira M, Bonomi PD, Camidge DR, Chu Q, Giaccone G, Khaira D, Ramalingam SS, Ranson MR, Dive C, McKeegan EM, Chyla BJ, Dowell BL, Chakravartty A, Nolan CE, Rudersdorf N, Busman TA, Mabry MH, Krivoshik AP, Humerickhouse RA, Shapiro Gl, Gandhi L: Phase II study of single-agent navitoclax (ABT-263) and biomarker correlates in patients with relapsed small cell lung cancer. Clin Cancer Res 2012, 18:3163-3169.

14. Hikita H, Takehara T, Shimizu S, Kodama T, Shigekawa M, Iwase K, Hosui A, Miyagi T, Tatsumi T, Ishida H, Li W, Kanto T, Hiramatsu N, Hayashi N: The $\mathrm{BCl}-\mathrm{xL}$ inhibitor, ABT-737, efficiently induces apoptosis and suppresses growth of hepatoma cells in combination with sorafenib. Hepatology 2010, 52:1310-1321.

15. Mazumder SCG, Al-Harbi S, Almasan A: Mcl-1 Phosphorylation Defines ABT-737 Resistance That Can Be Overcome by Increased NOXA Expression in Leukemic B cells. Cancer Res 2012, 72:3069-3079.

16. Perciavalle RM, Stewart DP, Koss B, Lynch J, Milasta S, Bathina M, Temirov J, Cleland MM, Pelletier S, Schuetz JD, Youle RJ, Green DR, Opferman JT: Anti-apoptotic MCL-1 localizes to the mitochondrial matrix and couples mitochondrial fusion to respiration. Nat Cell Biol 2012, 14:575-583.

17. Akgul C: $\mathrm{Mcl}-1$ is a potential therapeutic target in multiple types of cancer. Cell Mol Life Sci 2009, 68:1326-1336.

18. Lian J, Ni Z, Dai X, Su C, Smith AR, Xu L, He F: Sorafenib sensitizes (-)-gossypol-induced growth suppression in androgen-independent prostate cancer cells via Mcl-1 inhibition and Bak activation. Mol Cancer Ther 2012, 11:416-426.

19. Jane EP, Premkumar DR, DiDomenico JD, Hu B, Cheng SY, Pollack IF: YM-155 potentiates the effect of ABT-737 in malignant human glioma cells via survivin and $\mathrm{Mcl}-1$ downregulation in an EGFR-dependent context. Mol Cancer Ther 2013, 12:326-338.

20. Chen S, Dai Y, Harada H, Dent P, Grant S: Mcl-1 down-regulation potentiates ABT-737 lethality by cooperatively inducing Bak activation and Bax translocation. Cancer Res 2007, 67:782-791.

21. van Delft MF, Wei AH, Mason KD, Vandenberg CJ, Chen L, Czabotar PE, Willis SN, Scott CL, Day CL, Cory S, Adams JM, Roberts AW, Huang DC: The $\mathrm{BH} 3$ mimetic $\mathrm{ABT}-737$ targets selective $\mathrm{BCl}-2$ proteins and efficiently induces apoptosis via Bak/Bax if Mcl-1 is neutralized. Cancer Cell 2006, 10:389-399.

22. Thomas LW, Lam C, Edwards SW: Mcl-1; the molecular regulation of protein function. FEBS Lett 2010, 584:2981-2989.

23. Mills JRHY, Robert F, Chen SM, Malina A, Lin CJ, Trojahn U, Wendel HG, Charest A, Bronson RT, Kogan SC, Nadon R, Housman DE, Lowe SW, Pelletier J: mTORC1 promotes survival through translational control of Mcl-1. Proc Natl Acad Sci U S A 2008, 105:10853-10858.

24. Maurer U, Charvet C, Wagman AS, Dejardin E, Green DR: Glycogen synthase kinase-3 regulates mitochondrial outer membrane permeabilization and apoptosis by destabilization of MCL-1. Mol Cell 2006, 21:749-760.

25. Tse C, Shoemaker AR, Adickes J, Anderson MG, Chen J, Jin S, Johnson EF, Marsh KC, Mitten MJ, Nimmer P, Roberts L, Tahir SK, Xiao Y, Yang X, Zhang H, Fesik S, Rosenberg SH, Elmore SW: ABT-263: a potent and orally bioavailable Bcl-2 family inhibitor. Cancer Res 2008, 68:3421-3428.

26. Zhao $X$, Ogunwobi OO, Liu C: Survivin inhibition is critical for $\mathrm{BCl}-2$ inhibitor-induced apoptosis in hepatocellular carcinoma cells. PLOS ONE 2011, 6:e21980.

27. Wang G, Zhan Y, Wang H, Li W: ABT-263 sensitizes TRAIL-resistant hepatocarcinoma cells by downregulating the Bcl-2 family of anti-apoptotic protein. Cancer Chemother Pharmacol 2012, 69:799-805.

28. Vogt F, Lieber J, Dewerth A, Hoh A, Fuchs J, Armeanu-Ebinger S: BH3 mimetics reduce adhesion and migration of hepatoblastoma and hepatocellular carcinoma cells. Exp Cell Res 2013, 319:1443-1450.

29. Quinn BA, Dash R, Azab B, Sarkar S, Das SK, Kumar S, Oyesanya RA Dasgupta S, Dent P, Grant S, Rahmani M, Curiel DT, Dmitriev I, Hedvat M, Wei J, Wu B, Stebbins JL, Reed JC, Pellecchia M, Sarkar D, Fisher PB: Targeting Mcl-1 for the therapy of cancer. Expert Opin Investig Drugs 2011, 20:1397-1411. 
30. Isomoto HKS, Werneburg NW, Bronk SF, Guicciardi ME, Frank DA, Gores GJ: Interleukin 6 upregulates myeloid cell leukemia-1 expression through a STAT3 pathway in cholangiocarcinoma cells. Hepatology 2005, 42:1329-1338.

31. Hu J, Dang N, Menu E, De Bryune E, Xu D, Van Camp B, Van Valckenborgh E, Vanderkerken K: Activation of ATF4 mediates unwanted Mcl-1 accumulation by proteasome inhibition. Blood 2012, 119:826-837.

32. Wang JMCJ, Chen W, Kuo ML, Yen JJ, Yang-Yen HF: The antiapoptotic gene mcl-1 is up-regulated by the phosphatidylinositol 3-kinase/Akt signaling pathway through a transcription factor complex containing CREB. Mol Cell Biol 1999, 19:6195-6206.

33. Piret JP, Minet $E$, Cosse JP, Ninane $N$, Debacq C, Raes M, Michiels C: Hypoxia-inducible factor-1-dependent overexpression of myeloid cell factor-1 protects hypoxic cells against tert-butyl hydroperoxide-induced apoptosis. J Biol Chem 2005, 280:9336-9344.

34. Subramaniam D, Natarajan G, Ramalingam S, Ramachandran I, May R, Queimado L, Houchen CW, Anant S: Translation inhibition during cell cycle arrest and apoptosis: $\mathrm{Mcl}-1$ is a novel target for RNA binding protein CUGBP2. Am J Physiol Gastrointest Liver Physiol 2008, 294:G1025-G1032.

35. Domina AMVJ, Gregory MA, Hann SR, Craig RW: MCL1 is phosphorylated in the PEST region and stabilized upon ERK activation in viable cells, and at additional sites with cytotoxic okadaic acid or taxol. Oncogene 2004, 23:5301-5315.

36. Konopleva M, Milella M, Ruvolo P, Watts JC, Ricciardi MR, Korchin B, McQueen T, Bornmann W, Tsao T, Bergamo P, Mak DH, Chen W, McCubrey J, Tafuri A, Andreeff M: MEK inhibition enhances ABT-737-induced leukemia cell apoptosis via prevention of ERK-activated MCL-1 induction and modulation of MCL-1/BIM complex. Leukemia 2012, 26:778-787.

37. Morel CCS, White FM, Davis RJ: Mcl-1 integrates the opposing actions of signaling pathways that mediate survival and apoptosis. Mol Cell Biol 2009, 29:3845-3852.

38. Kodama YTK, Miura K, Schnabl B, Osawa Y, Brenner DA: Antiapoptotic effect of c-Jun N-terminal Kinase-1 through Mcl-1 stabilization in TNF-induced hepatocyte apoptosis. Gastroenterology 2009, 136:1423-1434.

39. Rahmani MAM, Attkisson E, Williams DC Jr, Ferreira-Gonzalez A, Grant S: Dual inhibition of $\mathrm{BCl}-2$ and $\mathrm{BCl}-\mathrm{xL}$ strikingly enhances PI3K inhibition-induced apoptosis in human myeloid leukemia cells through a GSK3- and Bim-dependent mechanism. Cancer Res 2013, 73:1340-1351.

40. Krishna S, Low IC, Pervaiz S: Regulation of mitochondrial metabolism: yet another facet in the biology of the oncoprotein Bcl-2. Biochem J 2011, 435:545-551.

41. Cheng P, Ni Z, Dai X, Wang B, Ding W, Rae Smith A, Xu L, Wu D, He F, Lian J: The novel $\mathrm{BH}-3$ mimetic apogossypolone induces Beclin-1- and ROS-mediated autophagy in human hepatocellular carcinoma [corrected] cells. Cell Death Dis 2013, 4:e489.

42. He F, Li J, Mu Y, Kuruba R, Ma Z, Wilson A, Alber S, Jiang Y, Stevens T, Watkins S, Pitt B, Xie W, Li S: Downregulation of endothelin-1 by farnesoid X receptor in vascular endothelial cells. Circ Res 2006, 98:192-199.

doi:10.1186/1476-4598-13-98

Cite this article as: Wang et al:: The $\mathrm{Bcl}-2 / \mathrm{xL}$ inhibitor ABT-263 increases the stability of Mcl-1 mRNA and protein in hepatocellular carcinoma cells. Molecular Cancer 2014 13:98.

\section{Submit your next manuscript to BioMed Central and take full advantage of:}

- Convenient online submission

- Thorough peer review

- No space constraints or color figure charges

- Immediate publication on acceptance

- Inclusion in PubMed, CAS, Scopus and Google Scholar

- Research which is freely available for redistribution

Submit your manuscript at www.biomedcentral.com/submit 